\title{
Efficacy of Zosteric Acid Sodium Salt on the Yeast Biofilm Model Candida albicans
}

\author{
Federica Villa • Betsey Pitts • Philip S. Stewart • Barbara Giussani • \\ Simone Roncoroni • Domenico Albanese - Carmen Giordano • Marta Tunesi • \\ Francesca Cappitelli
}

Received: 22 December 2010 / Accepted: 4 May 2011 /Published online: 26 May 2011

(C) Springer Science+Business Media, LLC 2011

\begin{abstract}
Candida albicans is the most notorious and the most widely studied yeast biofilm former. Design of experiments (DoE) showed that $10 \mathrm{mg} / \mathrm{L}$ zosteric acid sodium salt reduced $C$. albicans adhesion and the subsequent biofilm formation by at least $70 \%$, on both hydrophilic and hydrophobic surfaces of 96-well plates. Indeed, biofilm imaging revealed the dramatic impact of zosteric acid sodium salt on biofilm thickness and morphology, due to the inability of the cells to form filamentous structures while remaining metabolically active. In the same
\end{abstract}

F. Villa $\cdot$ F. Cappitelli $(\bowtie)$

Dipartimento di Scienze e Tecnologie Alimentari e

Microbiologiche, Università degli Studi di Milano,

via Celoria 2,

20133 Milan, Italy

e-mail: francesca.cappitelli@unimi.it

B. Pitts $\cdot$ P. S. Stewart

Center for Biofilm Engineering, Montana State University,

366 EPS Building, P.O. Box 173980, Bozeman, MT 59717, USA

B. Giussani $\cdot$ S. Roncoroni

Dipartimento di Scienze Chimiche e Ambientali,

Università degli Studi dell'Insubria,

via Valleggio 11,

20100 Como, Italy

D. Albanese

Dipartimento di Chimica Organica e Industriale,

Università degli Studi di Milano,

via Venezian 21,

20133 Milan, Italy

C. Giordano $\cdot$ M. Tunesi

Dipartimento di Chimica, Materiali e Ingegneria Chimica

"Giulio Natta", Politecnico di Milano,

via Luigi Mancinelli 7,

20133 Milan, Italy way, $10 \mathrm{mg} / \mathrm{L}$ zosteric acid sodium salt inhibited $C$. albicans biofilm formation when added after the adhesion phase. Contrary to zosteric acid sodium salt, methyl zosterate did not affect yeast biofilm. In addition, zosteric acid sodium salt enhanced sensitivity to chlorhexidine, chlorine, hydrogen peroxide, and cis-2-decenoic acid, with a reduction of 0.5 to $8 \log$ units. Preliminary in vitro studies using suitable primary cell based models revealed that zosteric acid sodium salt did not compromise the cellular activity, adhesion, proliferation or morphology of either the murine fibroblast line L929 or the human osteosarcoma line MG-63. Thus the use of zosteric acid sodium salt could provide a suitable, innovative, preventive, and integrative approach to preventing yeast biofilm formation.

\section{Introduction}

The adaptability of yeast cells allows them to abundantly colonize a wide range of surfaces to form biofilm, sessile communities exhibiting altered gene expression and structural features and displaying novel characteristics and phenotypes [24, 46]. Indeed, the biofilm lifestyle assists yeast cells in numerous aspects of their life cycle, offering protection against hydrodynamic forces, colonization of host tissues, the expression and enhancement of virulence traits, protection from stress, efficient nutrient capture, enhanced intercellular communication, as well as survival during harsh conditions and dispersal. Yeast colonization is of considerable social and economic importance in medical and technological settings as adhering cells can form recalcitrant biofilm in implanted devices, industrial installations, engineered systems, and on artistic surfaces $[6,18,35]$. 
Thus, an important goal today is the development of innovative anti-biofilm approaches aimed at preserving, for as long as possible, the value and usefulness of materials susceptible to biofilm formation. Given the common recalcitrance of yeast biofilms, and the limited innovation that has taken place in the field of antimicrobial discovery research and development over the past 20 years [9], it is now imperative to set up new biocide-free strategies to replace, or integrate with, traditional control treatments [8, 19, 36]. An ideal strategy would be to deprive microorganisms of their biofilm forming capability without affecting their existence [49]; this would also reduce the pressure of selecting resistant microorganisms and would, at the same time, restore the efficacy of antimicrobial agents [9].

In this context, the use of sub-lethal doses of bioinspired molecules able to interfere with key-steps orchestrating biofilm formation could provide new preventive strategies that do not necessarily kill cells but rather disarm them.

Zosteric acid is a natural product made by the seagrass Zostera marina, and it has been shown to deter, at nontoxic concentrations, fouling by marine bacteria, fungi, algae, barnacles, and tubeworms [5, 7, 27, 39, 43, 51]. Recently, Villa and colleagues [47] easily synthesized zosteric acid sodium salt using a non-patented process, and its efficacy was evaluated against two bacteria (Escherichia coli and Bacillus cereus) and two filamentous fungi (Aspergillus niger and Penicillium citrinum). The anti-biofilm activity of zosteric acid sodium salt was species-specific, and the reduction in microbial adhesion ranged from $23 \%$ to $99 \%$, depending on the environmental conditions. Zosteric acid sodium salt is not a chemorepellent but it has been shown to stimulate individual $E$. coli cell movement by increasing flagellin production, causing the bacteria to wander across the surface instead of adhering firmly and developing biofilm. In addition, this anti-biofilm compound retarded $E$. coli biofilm development with a significant decrease in biofilm biomass and mean thickness [47].

To date, despite this background of practical success, nobody has explored the performance of zosteric acid sodium salt in reducing yeast biofilms. Thus, the main goal of the present work has been to investigate the impact of zosteric acid sodium salt on the yeast biofilm model Candida albicans. Indeed, C. albicans, a well-characterized polymorphic fungus, is able to colonize widely varying niches like sand, plastic, stainless steel, skin surface, blood, liver, and other organs in a large range of environmental conditions $[6,10,13,14,48]$. In order to depict the flexibility of these yeast cells under different environmental parameters, and predict the performance of the anti-biofilm compound, a high-quality and validated model-based designs were applied [47]. Then, the activity of zosteric acid sodium salt on the structural development, morphology and thickness of formed $C$. albicans biofilm was explored. After demonstrating the efficacy of zosteric acid sodium salt, the next step was to gain information on the active group of the molecule. This lead to an evaluation of the potential of this compound to enhance the susceptibility of established $C$. albicans biofilm to some traditional antimicrobial agents and the new anti-biofilm compound cis-2-decenoic acid [15]. Finally, an in vitro study was carried out to investigate zosteric acid sodium salt cytocompatibility towards the murine fibroblast cell line L929 and the human osteosarcoma cell line MG-63.

\section{Methods}

Synthesis of Zosteric Acid Sodium Salt and Methyl Zosterate

Zosteric acid sodium salt was prepared by treating a $N, N$-dimethylformamide (DMF) solution of trans-4hydroxycinnamic acid with the sulfur trioxide pyridine complex, as previously described [47]. Methyl zosterate was synthesized as follows. In a two-necked round bottom flask, methyl 4-hydroxycinnamate (10 mmol, $1.78 \mathrm{~g})$ [34] was dissolved in anhydrous DMF (4 L). Then the sulfur trioxide pyridine complex $\mathrm{Py} \bullet \mathrm{SO}_{3}$ (14 mmol, $2.28 \mathrm{~g}$ ) was added and the resulting solution stirred at $50^{\circ} \mathrm{C}$ for $2 \mathrm{~h}$. After cooling to room temperature, $30 \% \mathrm{NaOH}$ was added dropwise to $\mathrm{pH}$ 7. The resulting mixture was extracted with $\mathrm{CH}_{2} \mathrm{Cl}_{2}(3 \times 10 \mathrm{~mL})$ and the aqueous phase was evaporated to dryness. The residue $(3.14 \mathrm{~g})$ was treated with $\mathrm{MeOH}$ at room temperature $(50 \mathrm{~mL})$ and the undissolved material filtered out (ordinary filter paper $67 \mathrm{~g} / \mathrm{m}^{2}$, Whatman). The evaporation of methanol afforded $2.50 \mathrm{~g}$ of a solid that was recrystallized from methanol to give $2.10 \mathrm{~g}$ of the title compound, yield $75 \%$.

Proton and carbon nuclear magnetic resonance $(1 \mathrm{H}$ and $13 \mathrm{C}$ NMR): ${ }^{1} \mathrm{H}$ NMR $\left(\mathrm{CD}_{3} \mathrm{OD}\right), \delta, 6.46$ (d, $1 \mathrm{H}, J=$ $16.0 \mathrm{~Hz}), 7.33$ (d, 2 H, J=8.6 Hz), 7.58 (d, $2 \mathrm{H}, J=8.6 \mathrm{~Hz})$, $7.67(\mathrm{~d}, 1 \mathrm{H}, J=16.0 \mathrm{~Hz}),{ }^{13} \mathrm{C} \mathrm{NMR}\left(\mathrm{D}_{2} \mathrm{O}\right), \delta, 52.7\left(\mathrm{CH}_{3}\right)$, $117.7(\mathrm{CH}), 122.2(\mathrm{CH}), 130.3(\mathrm{CH}), 132,3(\mathrm{C}), 145.3(\mathrm{CH})$, 153.3 (C), 170.3 (C). Mass spectrometry: electron spray ionization technique ESI-MS $m / z 257[\mathrm{M}-\mathrm{Na}]^{-}$. High performance liquid chromatography HPLC: Ascentis ${ }^{\mathrm{TM}}$ RPamide $(15 \times 4.6 \times 5 \mu \mathrm{m}) \mathrm{H}_{2} \mathrm{O}-\mathrm{CH}_{3} \mathrm{CN}(0.1 \%$ trifluoroacetic acid) $70-30,1 \mathrm{ml} / \mathrm{min}, \lambda 295 \mathrm{~nm}, 30^{\circ} \mathrm{C}, t_{\mathrm{R}}$ (methyl zosterate) $5.5 \mathrm{~min} ; t_{\mathrm{R}}$ (methyl 4-hydroxycinnamate) $14.1 \mathrm{~min}$.

\section{Water Solubility of Zosteric Acid Sodium Salt}

The solubility of the zosteric acid sodium salt was assessed by the shake-flask method. Briefly, $1.494 \mathrm{~g}$ of the 
compound was added to $5 \mathrm{~mL}$ of water in a glass vial. The vial was then stirred at room temperature for $24 \mathrm{~h}$, the solution containing the solid excess of the sample was filtered, giving $0.244 \mathrm{~g}$ of zosteric acid sodium salt. The filtrate was evaporated to dryness to generate $1.25 \mathrm{~g}$ of the compound, thus affording a solubility of $0.25 \mathrm{~g} / \mathrm{mL}$.

\section{C. albicans Strain and Growth Conditions}

The best-characterized C. albicans strain SC5314 (American Type Culture Collection MYA-2876, wild type), a known biofilm former, was used throughout the study $[20,28,32$, 37, 42]. The microorganism was maintained at $-80^{\circ} \mathrm{C}$ in suspensions containing $20 \%$ glycerol and $2 \%$ peptone, and was routinely grown in Yeast Nitrogen Base (YNB, Fisher Scientific Company) medium supplemented with $50 \mathrm{mM}$ glucose at $37^{\circ} \mathrm{C}$.

\section{Design of Experiments}

The anti-biofilm performance of zosteric acid sodium salt was investigated on both hydrophobic and hydrophilic surfaces. Zosteric acid sodium salt concentration $\left(\mathrm{X}_{1}\right)$, contact time $\left(\mathrm{X}_{2}\right.$, defined as the length of time the cells are in direct contact with both surface and zosteric acid sodium salt), temperature $\left(\mathrm{X}_{3}\right)$, and $\mathrm{pH}\left(\mathrm{X}_{4}\right)$ were studied as important variables that potentially influence biofilm formation [47]. The range of the variables was set up to explore cellular behavior and response to zosteric acid sodium salt in different environmental scenarios where there was no inhibition of vegetative cell growth. The following ranges were selected: $X_{1}(0-10 \mathrm{mg} / \mathrm{L}), X_{2}$ (30 min-24 h), $\mathrm{X}_{3}\left(10-40^{\circ} \mathrm{C}\right)$, and $\mathrm{X}_{4}(6-8)$.

The variables were coded in the range $-1 /+1$. The number of surface-bound cells quantified by fluorimetric measurements was chosen as the response variable.

A response surface design was run to fully characterize the process producing a response surface, and to model the response variations within the experimental region; a facecentered central composite design (CCD) was performed. The experiments, which involved three replicate measurements, were carried out in a randomized run order. The relationship between the independent variables and the response was evaluated by multiple linear regression; taking into consideration the linear terms, the two-term interactions and the quadratic terms. In the event of skewed response data, a square root (in case of slight asymmetry) or logarithmic transformation was performed prior to any calculation to render the distribution more symmetrical.

The significance of the regression was tested by comparing the variability caused by the regression model to the overall error $(\alpha=0.05)$. Models with a $P$ value higher than 0.05 were not taken into consideration. The goodness of fit of the polynomial models was evaluated by the coefficient of determination $R^{2}$, and the lack of fit (LOF) test $(\alpha=0.05)$ for the model from the analysis of variance (ANOVA) table. Values of LOF higher than 0.05 indicate that there might be a contribution to the variables-response relationship that the model does not take into account. The adjusted coefficient of determination $R^{2}$ adjusted $\left(R_{\text {adj }}{ }^{2}\right)$ was also calculated, taking into account the degrees of freedom in the model. When adding new model terms $R_{\text {adj }}{ }^{2}$ can decrease, giving an indication of whether or not a new coefficient actually improves the model or leads to overfitting. The modeling was performed using the software The Unscrambler version 9.8 (CAMO, Norway) and Microsoft Excel Worksheet. The experimental data points used to validate the mathematical models are shown in Table 2.

\section{Microplate-based Biofilm Assay}

Biofilm was assessed quantitatively using fluorochromelabeled cells in hydrophilic and hydrophobic 96-well blacksided plates as previously reported by Villa et al. [47]. Briefly, $200 \mu \mathrm{L}$ mineral medium $\left(0.70 \mathrm{~g} / \mathrm{L} \quad \mathrm{KH}_{2} \mathrm{PO}_{4}\right.$, $0.30 \mathrm{~g} / \mathrm{L} \quad \mathrm{K}_{2} \mathrm{HPO}_{4}, 0.50 \mathrm{~g} / \mathrm{L} \quad \mathrm{MgSO}_{4}, 2 \mathrm{~g} / \mathrm{L} \quad \mathrm{NaNO}_{3}$, $0.50 \mathrm{~g} / \mathrm{L} \mathrm{KCl}, 0.01 \mathrm{~g} / \mathrm{L} \mathrm{FeSO}_{4}$, pH 7) containing $10^{6}$ cells was placed in microtiter plate wells and subjected to different experimental conditions (for more details see the Design of Experiments (DoE) section). The microtiter plate wells were washed three times with $200 \mu \mathrm{L}$ phosphatebuffered saline (PBS, $0.01 \mathrm{M}$ phosphate buffer, $0.0027 \mathrm{M}$ potassium chloride $\mathrm{pH} 7.4$ at $25^{\circ} \mathrm{C}$, Sigma-Aldrich) and adhered cells were stained using $0.01 \%$ Fluorescent Brightener 28 vital dye (Sigma-Aldrich) in PBS for $10 \mathrm{~min}$ in the dark at room temperature. Fluorescence intensity was measured using the fluorometer VICTOR ${ }^{\mathrm{TM}} X$ Multilabel Plate Readers (Perkin Elmer) at excitation wavelength $433 \mathrm{~nm}$ and emission wavelength $335 \mathrm{~nm}$. A standard curve of fluorescence intensity versus cell number was determined and used to quantify the performance of the anti-biofilm compound. For all the combinations a negative control without the potential anti-biofilm agent was present. Three measurements were performed for each combination and their average was computed.

\section{Biofilm Assay in the CDC Reactor}

C. albicans biofilm was grown at $37^{\circ} \mathrm{C}$ on both glass and polycarbonate coupons at the Center for Disease Control Bioreactors (CDC reactor, Biosurface Technologies, Bozeman, MT, USA) as described previously [26], at flow rate of $250 \mathrm{~mL} / \mathrm{h}$. One bioreactor was run without zosteric acid sodium salt (control) and in the other bioreactor $10 \mathrm{mg} / \mathrm{L}$ zosteric acid sodium salt was added at different times during biofilm development. After the adhesion phase 
$(24 \mathrm{~h})$, an aliquot $(1 \mathrm{~mL})$ of the supernatant of both the control and treated samples was collected and plated on Tryptic Soy Agar (TSA, Fisher Scientific) to study the toxicity of the potential anti-biofilm compound on planktonic cells. For the same reason, the biomass present in the effluent drained from the $\mathrm{CDC}$ reactor at $72 \mathrm{~h}$ was quantified by colony counting. Coupons were collected at $24,31,45,53$, and $72 \mathrm{~h}$ and transferred to $10 \mathrm{~mL}$ PBS. Sessile cells were removed from the coupon surface by three cycles of $30 \mathrm{~s}$ sonication (Branson 3510, Branson Ultrasonic Corporation, Dunburry, CT) followed by $30 \mathrm{~s}$ vortex mixing [32]. Using this procedure, all the cells were dislodged from the coupons and clumps of cells were broken apart (data not shown). Serial dilutions of the resulting cell suspensions were plated on TSA and incubated overnight at $37^{\circ} \mathrm{C}$.

The biofilm assay was performed in two different ways: in the first assay, zosteric acid sodium salt was added to the bioreactor upon inoculation in the second, the potential anti-biofilm agent was added after the static phase (considered at $24 \mathrm{~h}$ biofilm) that represents the adhesion phase.

Biofilm Imaging by Confocal Laser Scanning Microscopy

After $72 \mathrm{~h}$, polycarbonate coupons were removed and the biofilm was stained with the fluorescent probe for yeast viability FUN1 (Molecular Probes). The biofilm was then incubated with $30 \mu \mathrm{M}$ FUN1 dye solution in PBS at $30^{\circ} \mathrm{C}$ in the dark for $30 \mathrm{~min}$ and then rinsed with PBS. Biofilm samples were visualized using a Leica TCS-SP2 AOBS confocal laser scanning microscope (CLSM) with excitation at $488 \mathrm{~nm}$, and emission $\geq 530 \mathrm{~nm}$ (green and red channels). Images were captured with a $63 \times, 0.9$ NA water immersion objective and analyzed with the software Imaris (Bitplane Scientific Software, Zurich, Switzerland). The experiments were repeated two times.

\section{Biofilm Sectioning}

The stained biofilms on the polycarbonate coupons were carefully covered with a layer of optimum cutting temperature (OCT formulation, Tissue-Tek) and placed in dry ice until completely frozen. The frozen samples were dipped vertically into the center of a cryosectioning mold filled with fresh OCT. The frozen samples were sectioned at $-19^{\circ} \mathrm{C}$ using a Leica CM1850 cryostat, and the 5- $\mu \mathrm{m}$ thick cryosections were mounted on Superfrost/ Plus microscope slides (Fisher Scientific), and observed using a Nikon Eclipse E800 microscope with a 10× dry objective. The sections were viewed both in transmission using differential interference contrast (DIC) optics and in the epifluorescence mode. The software MetaMorph
(Molecular Devices, Downingtown, PA) performed the image analysis and biofilm thickness measurements of the control and treated samples. More than five images per sample were taken for microscope analysis. For each picture, the biofilm thickness was measured at three different locations randomly selected along the profile. These measurements were used to calculate the average thickness and the associated standard deviation.

Antifungal Susceptibility Testing of Biofilm Cells

After $72 \mathrm{~h}$, the CDC reactor polycarbonate coupons were soaked in $10 \mathrm{~mL}$ agent solution. The following agents and concentrations were selected: (a) $50 \mathrm{mg} / \mathrm{L}$ chlorine; (b) $50 \mathrm{mg} / \mathrm{L}$ hydrogen peroxide; (c) 1,000 mg/L chlorhexidine digluconate; (d) $10 \mu \mathrm{M}$ cis-2-decenoic acid. The chlorine concentration was measured by the $N, N$-diethyl- $p$ phenylenediamine (DPD) method using a commercial DPD total chlorine test kit (Hach) with a DR/2010 portable spectrophotometer (Hach Comby) as per manufacturer's instructions. The antimicrobial experiments were performed comparing the treatment efficacy of the various agents against water. After $2 \mathrm{~h}$ incubation, the coupons were soaked in a neutralizing solution (distilled water or $100 \mathrm{mM}$ sodium thiosulfate for chlorine) for $5 \mathrm{~min}$ and then collected in PBS for colony counting, as previously reported in the biofilm assay section. A short incubation time was chosen to mimic daily cleaning and disinfection procedures in hospital and industrial settings. All antimicrobial experiments were conducted in triplicate. Antimicrobial efficacy was expressed as $\log _{10}$ microbial survival.

In situ analysis of antimicrobial susceptibility of untreated and zosteric acid sodium salt-treated biofilm was also carried out using the FC 270 flow cell apparatus (BioSurface Technologies, Bozeman, MT), the setup being performed according to the manufacturer's recommendations. The method consisted of determining the increase in fluorescence intensity of the cells within the biofilm during exposure to one of the four antimicrobial agents supplemented with $20 \mu \mathrm{g} / \mathrm{mL}$ propidium iodide (PI) in PBS. To verify the toxicity of the staining solution, live $C$. albicans planktonic cells were soaked in PI solution for $2 \mathrm{~h}$ and observed under the epifluorescent microscope.

The time scale of antimicrobial action of $1,000 \mathrm{mg} / \mathrm{L}$ chlorhexidine digluconate, the relative susceptibility of $C$. albicans cell forms to the drug formulation, and the removal of biomass from the biofilm were also visualized by the PI staining technique, using direct time-lapse microscopy inside intact fungal biofilm. After $72 \mathrm{~h}$, polycarbonate coupons with biofilm were removed from the CDC reactor and inserted into a flat plate flow cell (FC 270). A solution of $1,000 \mathrm{mg} / \mathrm{L}$ chlorhexidine supplemented with $20 \mu \mathrm{g} / \mathrm{mL}$ PI was pumped through the flow 
cells at a rate of $1 \mathrm{~mL} / \mathrm{min}$ rate for $2 \mathrm{~h}$. The increase in fluorescence intensity of the cells in the biofilm was imaged using confocal laser scanning microscopy with a $20 \times$ dry objective. Time series were collected at a single fixed height every $30 \mathrm{~s}$.

\section{In Vitro Cytotoxicity}

A concentration of $10 \mathrm{mg} / \mathrm{L}$ of zosteric acid sodium salt was tested. Cellular metabolic activity response was performed using a murine fibroblast cell line L929 (ECACC 85011425), whereas in vitro adhesion and morphological studies were performed with both immortalized murine fibroblast cell line L929 and MG-63 cell line (ECACC 86051601) from human osteosarcoma.

The cells were cultured, collected, counted, and diluted, as described elsewhere [17]. Cell viability after exposure to sample solution was assessed after 1, 2, 3 and 6 days by (3-(4, 5-dimethylthiazole-2-yl)-2, 5-diphenyltetrazoliumbromide) assay (MTT assay), performed as described elsewhere [12]. Briefly, $100 \mu \mathrm{L}$ cell suspensions of $10^{5} \mathrm{cell} / \mathrm{mL}$ were seeded into sterile 96-well culture plates (Corning Costar) and incubated to confluence. The culture medium was then replaced with a sample solution $(100 \mu \mathrm{L} /$ well, six replicates for each time point) for the testing wells, and fresh culture medium (100 $\mu \mathrm{L} /$ well, three replicates for each time point) for the control wells. The plates were incubated at $37^{\circ} \mathrm{C}$ with $5 \%$ $\mathrm{CO}_{2}$ in a humidified atmosphere for 1, 2, 3, and 6 days. Ten microliters of MTT (Sigma-Aldrich) solution $(5 \mathrm{mg} / \mathrm{mL}$ in culture medium containing FBS) was added to each well, the plates were incubated for $4 \mathrm{~h}$ and then the medium removed for inversion; $100 \mu \mathrm{L}$ of dimethyl sulfoxide (Sigma-Aldrich) were added to each well, mixed for 30 min until complete dissolution of the crystals. Absorbance was measured by a plate reader (Tecan Genius Plus), using a test wavelength of $570 \mathrm{~nm}$ and a reference wavelength of $630 \mathrm{~nm}$. At least three replicates for control and testing wells were performed.

Cellular adhesion and morphology was performed using commercially pure grade II 15-mm-diameter titanium samples, ultrasonically cleaned (Branson Automatically Cleaning) with acetone (Sigma-Aldrich, Germany), sterilized by $70 \%(v / v)$ ethanol rinsing followed by UV irradiation $(254 \mathrm{~nm})$ and placed within 12-well polystyrene tissue culture plates (Corning, Costar-Celbio, Italy). In vitro adhesion and morphological studies were performed with immortalized cells: MG-63 cell line (ECACC 86051601) from human osteosarcoma, and L929 cell line (ECACC 85011425) from mouse areolar adipose tissue. Before seeding, the cells were cultured, collected, resuspended in standard culture medium without and with zosteric acid sodium salt and counted as reported by Giordano et al. [23]. Then, $10^{5}$ cells were seeded on titanium samples and incubated in order to let cells adhere on the material. After $1 \mathrm{~h}, 1 \mathrm{~mL}$ of the culture medium was added to each well and all investigations were performed in triplicate; 24 and $48 \mathrm{~h}$ after seeding, the medium was discarded and the samples incubated overnight at $4{ }^{\circ} \mathrm{C}$ with $1.5 \%(v / v)$ glutaraldehyde solution (Fluka, Germany) in $0.1 \mathrm{M}$ sodium cacodylate (Fluka, Germany). This fixing solution was then removed and the samples washed with $0.1 \mathrm{M}$ sodium cacodylate and incubated overnight at $4{ }^{\circ} \mathrm{C}$ in the same solution. The following day, the sodium cacodylate was discarded, and the samples washed twice with distilled water and air dried. Before the environmental scanning electron microscope (Zeiss Evo $50 \mathrm{EP}$ ) observation, the samples were gold-sputtered (Edwards, Sputter Coater S150B).

\section{Statistical Analysis}

ANOVA, via a software run in MATLAB environment (Version 7.0, The MathWorks Inc, Natick, USA), was applied to statistically evaluate any significant differences among the samples. Tukey's honestly significant different test (HSD) was used for pairwise comparison to determine the significance of the data. Statistically significant results were depicted by $P$ values $<0.05$.

\section{Results}

Zosteric Acid Sodium Salt Negatively Affected C. albicans Adhesion Ability

Ninety-six-well microtiter plates experiments planned through a DoE approach were used to study the performance of zosteric acid sodium salt and to identify important variables driving C. albicans adhesion. The experimental matrix design and the summary of statistical results for the CCD is given in Table 1. The main factors, interactions among the factors and the quadratic effects are reported in Eqs. 1 and 2 for the hydrophilic and hydrophobic surface, respectively. The analysis of variance detected as significant, in the case of the hydrophilic surface, the model terms $\mathrm{X}_{1}$ (zosteric acid sodium salt concentration), $\mathrm{X}_{2}$ (time), $\mathrm{X}_{1}{ }^{2}$ (quadratic term of the zosteric acid sodium salt concentration) and $\mathrm{X}_{1} \mathrm{X}_{2}$ (interaction of the two variables). The colonization process of $C$. albicans on the hydrophobic surface showed a more complex pattern, which depends upon the fact that the linear terms of all design variables, the quadratic term of $X_{1}$ and $\mathrm{X}_{2}$, as well as the interactions $\mathrm{X}_{1} \mathrm{X}_{3}, \mathrm{X}_{1} \mathrm{X}_{4}$ and $\mathrm{X}_{2} \mathrm{X}_{4}$ were detected as significant factors $(P$ values $<0.05)$ affecting the number of adhered cells. Validation experiments (Table 2) were carried out within the experimental domain. From the operative point of view, regions with fewer adhered cell numbers were chosen to verify the reliability of the models in the most interesting areas. 
Table 1 Face central composite design matrix and corresponding output responses on hydrophilic and hydrophobic surface

\begin{tabular}{|c|c|c|c|c|c|c|c|c|c|c|c|c|c|c|}
\hline \multirow[t]{3}{*}{ Exp. No. } & \multicolumn{5}{|c|}{ Hydrophilic surface } & \multicolumn{9}{|c|}{ Hydrophobic surface } \\
\hline & \multicolumn{2}{|c|}{ Coded variable } & \multicolumn{2}{|c|}{ Original value } & \multirow{2}{*}{$\begin{array}{l}\text { No. adhered cells } \\
\text { Average }\left(\times 10^{3}\right)\end{array}$} & \multicolumn{4}{|c|}{ Coded variable } & \multicolumn{4}{|c|}{ Original value } & \multirow{2}{*}{$\begin{array}{l}\text { No. adhered cells } \\
\text { Average }\left(\times 10^{3}\right)\end{array}$} \\
\hline & $\mathrm{X}_{1}$ & $\mathrm{X}_{2}$ & $\mathrm{X}_{1}$ & $\mathrm{X}_{2}$ & & $\mathrm{X}_{1}$ & $\mathrm{X}_{2}$ & $\mathrm{X}_{3}$ & $\mathrm{X}_{4}$ & $\mathrm{X}_{1}$ & $\mathrm{X}_{2}$ & $\mathrm{X}_{3}$ & $\mathrm{X}_{4}$ & \\
\hline 1 & -1 & -1 & 0 & 0.5 & 6.87 & -1 & -1 & -1 & -1 & 0 & 0.5 & 10 & 6 & 5.28 \\
\hline 2 & 1 & -1 & 10 & 0.5 & 4.77 & 1 & -1 & -1 & -1 & 10 & 0.5 & 10 & 6 & 3.16 \\
\hline 3 & -1 & 1 & 0 & 24 & 55.2 & -1 & 1 & -1 & -1 & 0 & 24 & 10 & 6 & 24.7 \\
\hline 4 & 1 & 1 & 10 & 24 & 14.1 & 1 & 1 & -1 & -1 & 10 & 24 & 10 & 6 & 12.8 \\
\hline 5 & 1 & 0 & 10 & 12.25 & 12.2 & -1 & -1 & 1 & -1 & 0 & 0.5 & 40 & 6 & 8.55 \\
\hline 6 & -1 & 0 & 0 & 12.25 & 24.7 & 1 & -1 & 1 & -1 & 10 & 0.5 & 40 & 6 & 8.55 \\
\hline 7 & 0 & 1 & 5 & 24 & 17.8 & -1 & 1 & 1 & -1 & 0 & 24 & 40 & 6 & 5.23 \\
\hline 8 & 0 & -1 & 5 & 0.5 & 1.49 & 1 & 1 & 1 & -1 & 10 & 24 & 40 & 6 & 5.23 \\
\hline 9 & 0 & 0 & 5 & 12.25 & 13.8 & -1 & -1 & -1 & 1 & 0 & 0.5 & 10 & 8 & 7.96 \\
\hline 10 & 0 & 0 & 5 & 12.25 & 9.38 & 1 & -1 & -1 & 1 & 10 & 0.5 & 10 & 8 & 3.47 \\
\hline 11 & & & & & & -1 & 1 & -1 & 1 & 0 & 24 & 10 & 8 & 85.4 \\
\hline 12 & & & & & & 1 & 1 & -1 & 1 & 10 & 24 & 10 & 8 & 20.1 \\
\hline 13 & & & & & & -1 & -1 & 1 & 1 & 0 & 0.5 & 40 & 8 & 10.1 \\
\hline 14 & & & & & & 1 & -1 & 1 & 1 & 10 & 0.5 & 40 & 8 & 4.08 \\
\hline 15 & & & & & & -1 & 1 & 1 & 1 & 0 & 24 & 40 & 8 & 22.9 \\
\hline 16 & & & & & & 1 & 1 & 1 & 1 & 10 & 24 & 40 & 8 & 11.0 \\
\hline 17 & & & & & & 1 & 0 & 0 & 0 & 10 & 12.25 & 25 & 7 & 10.1 \\
\hline 18 & & & & & & -1 & 0 & 0 & 0 & 0 & 12.25 & 25 & 7 & 15.8 \\
\hline 19 & & & & & & 0 & 1 & 0 & 0 & 5 & 24 & 25 & 7 & 10.1 \\
\hline 20 & & & & & & 0 & -1 & 0 & 0 & 5 & 0.5 & 25 & 7 & 5.06 \\
\hline 21 & & & & & & 0 & 0 & 1 & 0 & 5 & 12.25 & 40 & 7 & 11.5 \\
\hline 22 & & & & & & 0 & 0 & -1 & 0 & 5 & 12.25 & 10 & 7 & 10.7 \\
\hline 23 & & & & & & 0 & 0 & 0 & 1 & 5 & 12.25 & 25 & 8 & 10.8 \\
\hline 24 & & & & & & 0 & 0 & 0 & -1 & 5 & 12.25 & 25 & 6 & 7.13 \\
\hline 25 & & & & & & 0 & 0 & 0 & 0 & 5 & 12.25 & 25 & 7 & 10.2 \\
\hline 26 & & & & & & 0 & 0 & 0 & 0 & 5 & 12.25 & 25 & 7 & 8.15 \\
\hline
\end{tabular}

$X_{1}$ zosteric acid sodium salt concentration, $\mathrm{mg} / \mathrm{L} ; X_{2}$ time, $\mathrm{h} ; X_{3}$ temperature, ${ }^{\circ} \mathrm{C} ; X_{4} \mathrm{pH}$. The variables were coded as -1 (lower value), 0 (central value) and +1 (maximum value). Average standard deviation $10.8 \%$

Table 2 shows the predicted values with an estimate of the experimental standard deviation calculated by the model as the root mean squared error of cross validation (RMSECV) and the experimental values with their standard

Table 2 Comparison of predicted and experimental values of the response (number of adhered cells).

\begin{tabular}{lllll}
\hline Type of surface & Parameters & Predicted value \pm RMSECV $\left(\times 10^{3}\right)$ & Experimental value \pm SD $\left(\times 10^{3}\right)$ & $10.5 \pm 0.9$ \\
\hline $\mathrm{Hl}$ (Sqrt resp.) & $\mathrm{X}_{1}: 4.5$ & $10.0 \pm 1.3$ & \\
& $X_{2}: 12.25$ & & $7.4 \pm 0.5$ & $5.2 \%$ \\
$\mathrm{Hb}$ (ln resp.) & $\mathrm{X}_{1}: 4$ & $7.2 \pm 0.1$ & \\
& $X_{2}: 6$ & & \\
& $\mathrm{X}_{3}: 17.5$ & & \\
& $\mathrm{X}_{4}: 7$ & & \\
& & & \\
\hline
\end{tabular}

The predicted values reported the root mean squared error of cross validation (RMSECV) for measuring the predictive ability of the model. The experimental values reported the mean of three replicates and the standard deviation (SD). Deviation was calculated as follows: [(experimental value - predicted value $) \times 100] /$ predicted value

$X_{1}$ zosteric acid sodium salt concentration, $\mathrm{mg} / \mathrm{L} ; X_{2}$ temperature, ${ }^{\circ} \mathrm{C} ; X_{3}$ time, $\mathrm{h} ; X_{4} \mathrm{pH} ; H l$ hydrophilic surface; $H b$ hydrophobic surface 
deviation. The results show that the experimentally determined responses were not statistically different from the predicted ones. Moreover, it is worthwhile to note that the calculated RMSECV and the experimental standard deviation are in the same order of magnitude. These results confirm the reliability of the models.

\section{C. albicans Model on Hydrophilic Surface}

To study the relationship between the response (no. of adhered cells) and the experimental levels for each of the factors the fitted polynomial equation and surface plots were computed (Eq. 1 reports only the significant terms, ${ }^{*} P<0.05$, $* * P<0.01, * * * P<0.001$; Fig. 1a):

Sqrt(number of adhered cells)

$$
\begin{aligned}
= & 96.63-29.49 \mathrm{X}_{1}(* *)+49.44 \mathrm{X}_{2}(* * *) \\
& +32.23 \mathrm{X}_{1}{ }^{2}(*)-25.58 \mathrm{X}_{1} \mathrm{X}_{2}(*)
\end{aligned}
$$

The $R^{2}$ value for cross validation, $0.894\left(R^{2} 0.967-\right.$ $R_{\text {adj }}^{2} 0.941$ ), with a LOF of 0.689 , made the model significant. The addition of zosteric acid sodium salt decreases the response at any time, with this effect being much greater at longer times (Fig. 1a). The response decreases quite fast up to the center of the range, and then becomes almost constant. An increase of time produces an increase of the response, this being much greater at lower concentration of zosteric acid sodium salt (Fig. 1a). The regression model predicted that after $24 \mathrm{~h}$ of exposure, the minimum in the response would correspond to the maximum concentration of zosteric acid sodium salt, reducing cell adhesion on the hydrophilic surface by $72 \%$.

\section{C. albicans Model on Hydrophobic Surface}

The model equation, considering only statistically significant coefficients (Eq. 2, ${ }^{*} P<0.05, * * P<0.01, * * * P<0.001$ )
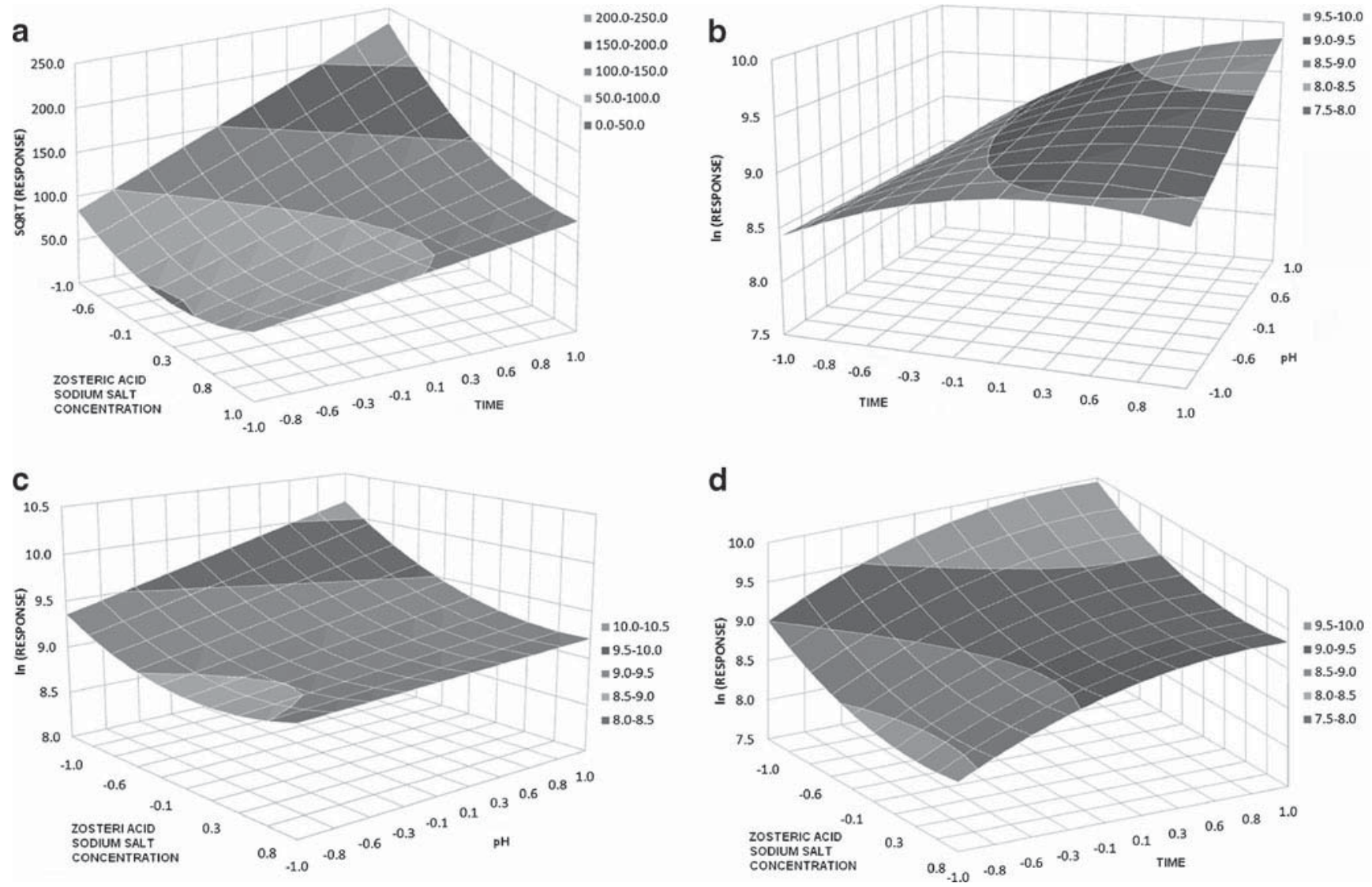

Figure $13 \mathrm{D}$ response surfaces of $C$. albicans adhesion on hydrophilic a and hydrophobic surface $\mathbf{b}-\mathbf{d}$. Plots show the effect of zosteric acid sodium salt vs. time (a), time vs. $\mathrm{pH}$ when zosteric acid sodium salt concentration and temperature were kept at the central value (b), zosteric acid sodium salt concentration vs. $\mathrm{pH}$ when time and

temperature were kept at the central value (c) and zosteric acid sodium salt concentration vs. time when temperature and $\mathrm{pH}$ were kept at the central value (d). Ranges in the legends represent the square root $\mathbf{a}$ or the $\log \mathbf{b}-\mathbf{d}$ of the number of adhered cells 
and giving an $R^{2}$ for prediction of $0.851\left(R^{2} 0.957-R_{\mathrm{adj}}^{2}\right.$ 0.928), follows:

$\operatorname{Ln}$ (number of adhered cells)

$$
\begin{aligned}
= & 9.168-0.308 \mathrm{X}_{1}(* * *)+0.477 \mathrm{X}_{2}(* * *) \\
& -0.134 \mathrm{X}_{3}(* *)+0.236 \mathrm{X}_{4}(* * *)+0.285 \mathrm{X}_{1}^{2}(*) \\
& -0.285 \mathrm{X}_{2}^{2}(*)+0.112 \mathrm{X}_{1} \mathrm{X}_{3}(*) \\
& -0.172 \mathrm{X}_{1} \mathrm{X}_{4}(* *)-0.391 \mathrm{X}_{2} \mathrm{X}_{3}(* * *) \\
& +0.248 \mathrm{X}_{2} \mathrm{X}_{4}(* * *)
\end{aligned}
$$

From the model, it emerged that C. albicans adhesion on a hydrophobic surface is stronger at higher $\mathrm{pH}$ values (Fig. 1b, c). Zosteric acid sodium salt slowed down the effect of the colonization-promoting factor $\mathrm{pH}$ (Fig. 1c). The number of adhered cells decreased until reaching an optimum concentration value of zosteric acid sodium salt and, after that, the number increased again as a consequence of the quadratic effect (positive sign) of the $\mathrm{X}_{1}$ variable. In addition, the antifoulant counteracted the surface colonization process promoted by the variable time, an effect that became more evident when the zosteric acid sodium salt concentration increased (Fig. 1d). Figure 1b shows the interaction $\mathrm{X}_{2} \mathrm{X}_{4}$. It can be seen that at low $\mathrm{pH}$ time has no effect, while at high $\mathrm{pH}$ the response increases with time; on the other side, at shorter times the $\mathrm{pH}$ has no effect, while at longer times the response increase with $\mathrm{pH}$.

The regression prediction model showed that to counteract adhesion over time $10 \mathrm{mg} / \mathrm{L}$ zosteric acid sodium salt were needed. On comparing the best experimental conditions promoting $C$. albicans adhesion with those that discouraged surface colonization it was found that the presence of the salt led to a $96 \%$ reduction in cell adhesion.

\section{Zosteric Acid Sodium Salt Decreased Biofilm Biomass in CDC Reactor}

The use of the CDC biofilm reactor allowed the formation of complex, dense, mature biofilms containing approximately $10^{9} \mathrm{CFU} /$ disk within $96 \mathrm{~h}$.

The potential antifoulant did not affect the vegetative growth of $C$. albicans. After a static time of $24 \mathrm{~h}$ in the $\mathrm{CDC}$ reactor, $1.5 \times 10^{7} \pm 3.0 \times 10^{6} \mathrm{CFU} / \mathrm{mL}$ were obtained without the potential anti-biofilm compound and $1.3 \times 10^{7} \pm$ $1.4 \times 10^{6} \mathrm{CFU} / \mathrm{mL}$ in its presence $(10 \mathrm{mg} / \mathrm{L}$ zosteric acid sodium salt). In the effluent drained from the CDC reactor no statistically significant difference was found between the control and the treated samples ( $P>0.05$ data not shown).

Biofilm formation without and with $10 \mathrm{mg} / \mathrm{L}$ zosteric acid sodium salt on both glass and polycarbonate coupons was monitored over $72 \mathrm{~h}$, measuring biofilm biomass by colony counting. Figure 2 shows the results of the $C$. albicans biofilm growth without and with zosteric acid sodium salt at different time points. After $24 \mathrm{~h}$ in static conditions, the biofilm growth curve revealed significant differences in cell adhesion between the control and treated samples $\left(P_{\text {hydrophilic: }}: 1.06 \times 10^{-10}\right.$; $P_{\text {hydrophobic }}: 1.02 \times 10^{-13}$ ). The presence of zosteric acid sodium salt reduced cell adhesion by $80 \%$ and $70 \%$ for the hydrophilic and hydrophobic surfaces respectively. Although there was an initial inhibition of cell adhesion, the biofilm biomass in the treated system increased over time. Even so, after $72 \mathrm{~h}$, the biofilm biomass was 5 - to 30 -fold less in the presence of zosteric acid sodium salt, the final reduction being at least $80 \%$ on both hydrophilic and hydrophobic surfaces.

Zosteric Acid Sodium Salt Affected the Thickness and Morphology of C. albicans Biofilm

Microscopic examination of the untreated samples indicates that the cells underwent the budded-to-hyphal-form transition, and showed significant hyphal elongation in CDC-
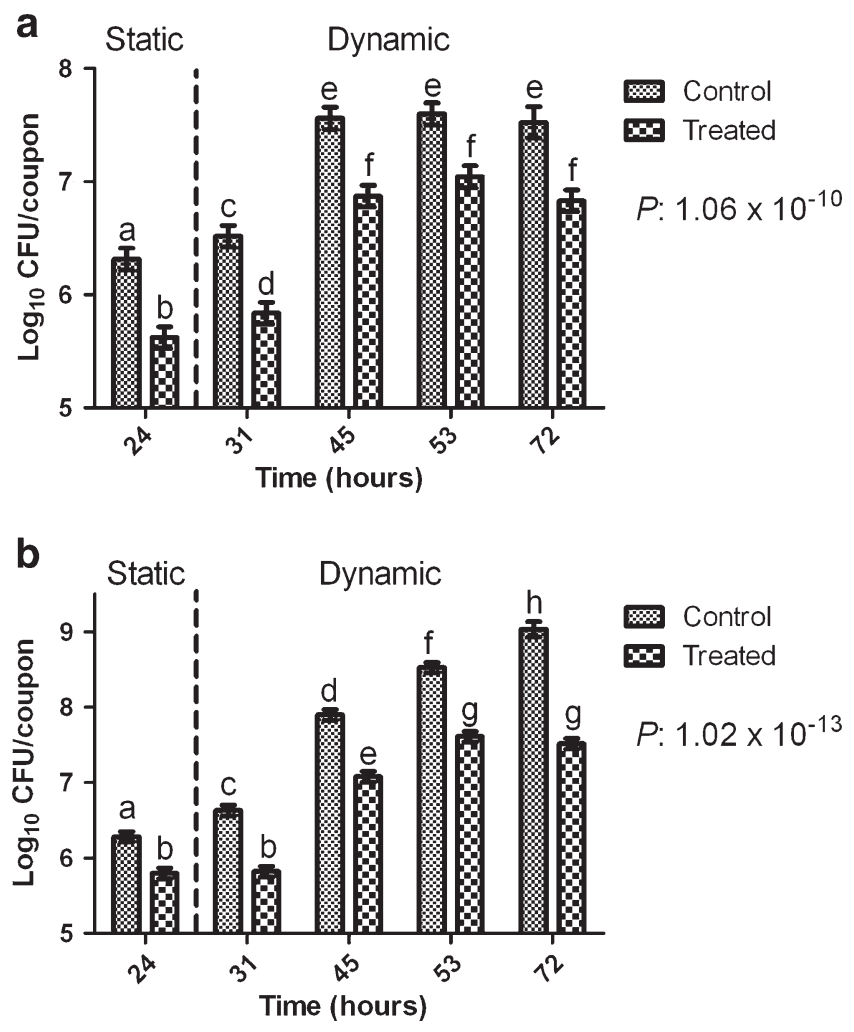

Figure 2 C. albicans biofilm growth curve on $\mathbf{a}$ hydrophilic and $\mathbf{b}$ hydrophobic surface. The graph provides the $P$ value obtained by ANOVA analysis. Error bars display the honestly significant difference (HSD) intervals using Tukey multiple comparison with a $95 \%$ confidence level (Tukey's HSD, $P<0.05$ ). According to post-hoc analysis, means sharing the same letter are not significantly different from each other. The statistical analysis was performed separately for each surface 
grown biofilm. The untreated samples showed a biofilm composed of a basal monolayer of yeast cells covered by an intricate network of hyphal elements, resulting in a thick compact structure covering the entire coupon surface (Fig. 3a). However, in the presence of $10 \mathrm{mg} / \mathrm{L}$ of an antibiofilm agent different biofilm morphological patterns were produced. Projection analysis as well as vertical sectioning of 3D-reconstructed images revealed that the treated biofilm contained mainly yeast forms and very few filamentous structures, indicating that the anti-biofilm agent affected the morphology of the C. albicans biofilm (Fig. 3c).

Cryosectioning combined with microscopy revealed that the $C$. albicans biofilm formed in the presence of zosteric acid sodium salt (biofilm thickness $99 \pm 38 \mu \mathrm{m}$ ) was significantly thinner than the film formed without the salt (biofilm thickness $337 \pm 80 \mu \mathrm{m}$; Fig. $3 \mathrm{~b}$, d). In both the control and the treated samples, FUN1 staining resulted in an intense red fluorescent signal, revealing metabolically active cells. Thus, FUN1 viability staining and cryosections of biofilm samples indicated that zosteric acid sodium salt induced a significant reduction, $70 \%$, in biofilm thickness, without killing cells.

\section{Zosteric Acid Sodium Salt Affected C. albicans Biofilm when Added After the Adhesion Phase}

Fungal biofilm showed significant differences when the zosteric acid sodium salt regime was initiated after the adhesion phase $(24 \mathrm{~h})$. Biofilm development was monitored over $72 \mathrm{~h}$ in both control and treated samples, revealing that the biomass of the treated samples was reduced by $80 \%$ (72 h-old biofilm, control sample $9.53 \pm 0.13 \log _{10} \mathrm{CFU} /$ coupon; treated sample $8.83 \pm 0.17 \log _{10}$ CFU/coupon, $P$ : 0.042). Side views of $3 D$ reconstructed CLSM images of the treated samples depicted microcolonies of predominantly yeast forms, and very few filamentous structures of abnormal length (Fig. 4a). These morphostructural alterations were also shown by biofilm sectioning. Again, images captured from frozen sections showed that the average thickness of the 72-h-old biofilm growth without zosteric acid sodium salt (biofilm thickness $372 \pm 61 \mu \mathrm{m}$ ) was significantly greater than the biofilm observed in the treated samples (biofilm thickness $87 \pm 46 \mu \mathrm{m}$ ), there being a significant reduction, $77 \%$, in biofilm thickness (Fig. 4b).

\section{Methyl Zosterate had no Anti-biofilm Properties}

To elucidate the active site of the molecule, the carboxylic group was blocked through the formation of the methyl ester. The esterified compound affected neither the morphology of fungal biofilm nor its architecture, as demonstrated by biomass quantification ( $72 \mathrm{~h}$-old biofilm, control sample $8.80 \pm 0.22 \log _{10} \mathrm{CFU} /$ coupon; treated sample 8.70 $\pm 0.30 \log _{10}$ CFU/coupon), CLSM and cryosectioning imaging. In fact, after $72 \mathrm{~h}$, there was no significant difference in the biomass population of untreated and methyl zosterate-treated biofilm $(P>0.05)$. As revealed by CLSM, untreated and treated biofilm was similar in structural morphology, and consisted of a complex biphasic structure of both yeast cells and filaments (Fig. 4c). In addition, cryosectioning imaging and measurements revealed no statistically significant difference between control (biofilm thickness $372 \pm 61 \mu \mathrm{m}$ ) and treated samples

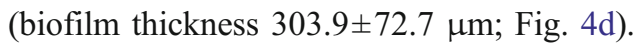

Figure 3 Biofilm produced by $C$. albicans. a, b zosteric acid sodium salt-free sample (control); c, d anti-biofilm compound added at the beginning of the experiment. The biofilm was visualized after staining with the fluorescence probe FUN1. Bars represent $40 \mu \mathrm{m}$. Cryosectioning images from $C$. albicans biofims grown without $\mathbf{b}$ and with d zosteric acid sodium salt. Images were obtained by superimposing the same view in DIC and epifluorescence mode. Live cells were stained in red, whereas dead cells appeared in green. Bars represent $160 \mu \mathrm{m}$

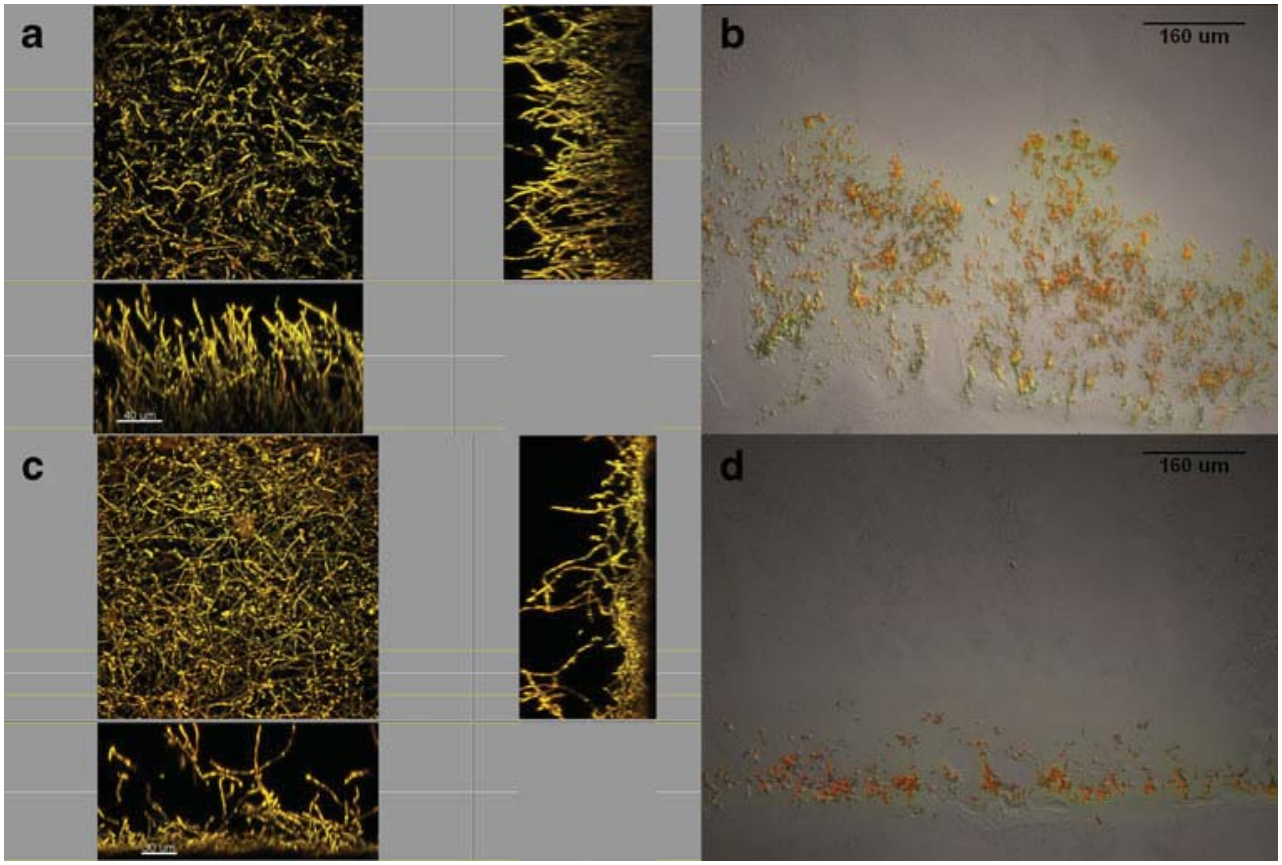


Figure 4 Biofilm produced by C. albicans. a, b zosteric acid sodium salt added after the adhesion phase; $\mathbf{c}, \mathbf{d}$ methyl zosterate examined by confocal laser microscopy (first column) and biofilm sectioning (second column). The biofilm was visualized after staining with the fluorescence probe FUN1. Bars in the CLSM images represent $40 \mu \mathrm{m}$. Cryosectioning images from $C$. albicans biofilms grown when zosteric acid sodium salt was added after the adhesion phase (b) and with the methyl zosterate (d). Images were obtained by superimposing the same view in DIC and epifluorescence mode. Live cells were stained in red, whereas dead cells appeared in green. Bars represent $160 \mu \mathrm{m}$

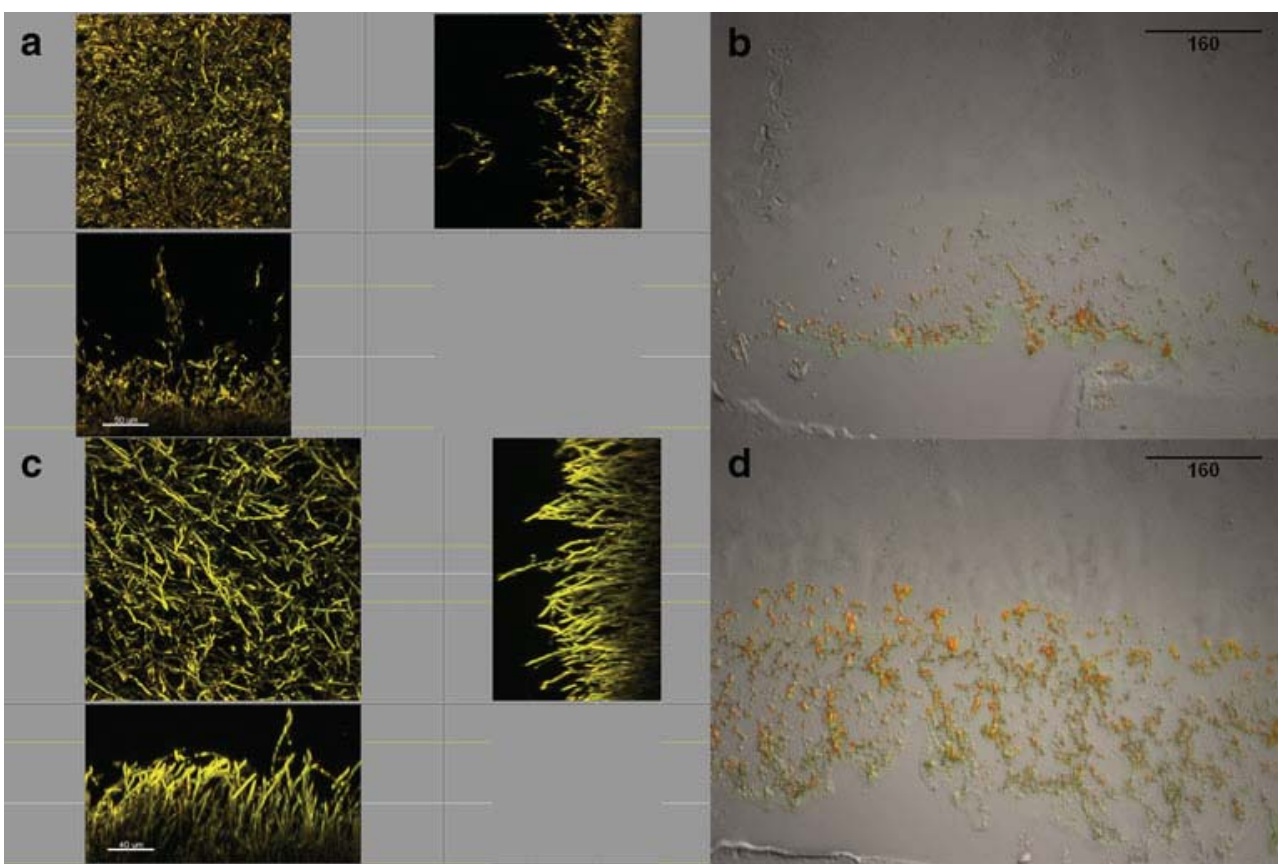

Enhanced Antimicrobial Agent Susceptibility of $C$. albicans Biofilm Formed in the Presence of Zosteric Acid Sodium Salt

To evaluate the antimicrobial agent susceptibility of $C$. albicans biofilm formed without zosteric acid sodium salt versus its growth in the presence of $10 \mathrm{mg} / \mathrm{L}$ of the antibiofilm compound, log unit reductions were compared $(P: 0)$, as shown in Fig. 5.

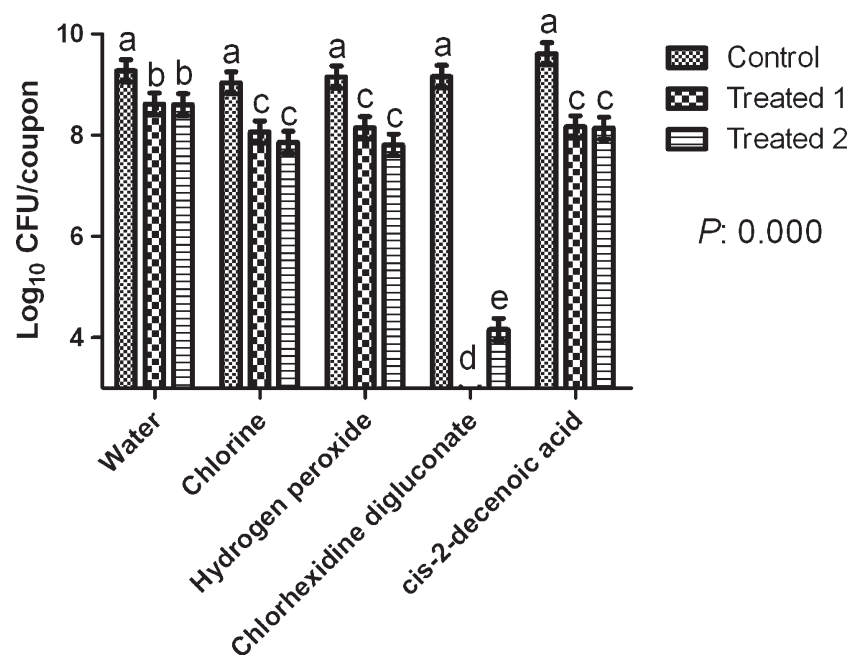

Figure 5 Antifungal susceptibility test. Control without zosteric acid sodium salt; Treated 1 zosteric acid sodium salt added at the beginning of the experiment; Treated 2 zosteric acid sodium salt added after the adhesion phase. The graph provides the $P$ value obtained by ANOVA analysis. Error bars display the honestly significant difference (HSD) intervals using Tukey's multiple comparison with a 95\% confidence level (Tukey's HSD, $P<0.05$ ). According to post-hoc analysis, means sharing the same letter are not significantly different from each other
The untreated biofilm appeared completely invulnerable to chlorine, hydrogen peroxide, chlorhexidine digluconate and cis-2-decenoic acid, as no statistically significant differences were found between mature $72 \mathrm{~h}$ biofilm exposed to water and biofilm exposed to antifungals. In the same way, in biofilm with zosteric acid sodium salt, the viable cell counts from chlorine, hydrogen peroxide and cis-2-decenoic acid-treated coupons were only slightly less compared to those of the drug-free control, the reduction being 0.5 to $0.8 \log$ units.

A reduction of 8 and $4.5 \log$ units was observed after $1,000 \mathrm{mg} / \mathrm{L}$ chlorhexidine digluconate exposure when the antibiofilm compound was added at the beginning of the experiment and after the adhesion phase respectively. PI in aqueous solution did not produce detectable fluorescence in planktonic cells after $2 \mathrm{~h}$ exposure (data not shown), suggesting that false positive signals were not produced. Even after a 2-h exposure to chlorhexidine digluconate most of the zosteric acid sodium salt-free biofilm remained unstained (Fig. 6a-c), there being only a small portion of the filamentous structures labeled with PI (Fig. 6c). There was no trace of fluorescence from other cell forms. For the zosteric acid sodium salt-treated samples, flowing the antimicrobial agent through the reactor led to a gradual increase in red fluorescence within the first $2 \mathrm{~h}$ (Fig. $6 \mathrm{~d}-\mathrm{f}$ ). At the end of this experiment, all the yeast forms inside the field of vision appeared labeled with PI, demonstrated by superimposing the transmission and fluorescent images. Interestingly, in the zosteric acid sodium salt-grown biofilm, PI penetration appeared greater in the yeast forms than in the filamentous. There was no evidence that any treatment caused the removal or detachment of biomass from the biofilm. 

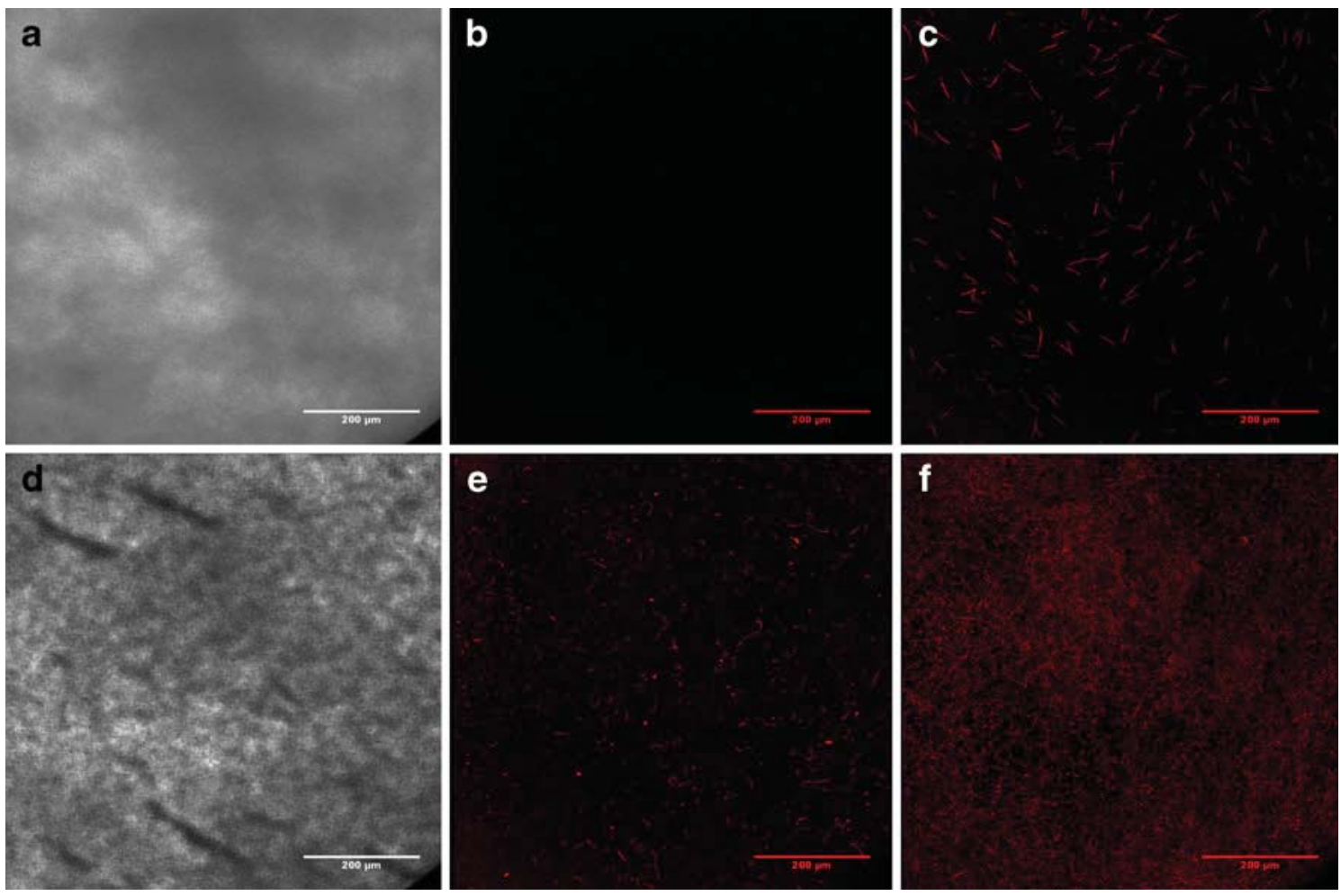

Figure 6 Action of chlorhexidine digluconate on zosteric acid sodium salt-free (first row, a-c) and zosteric acid sodium salt-treated C. albicans biofilm (second row, $\mathbf{d}-\mathbf{f}$ ). Cells are stained with propidium iodide. Panels a and $\mathbf{d}$ show transmission images of the

Zosteric Acid Sodium Salt did not Compromise Soft Tissue Cellular Activity

For the L929 fibroblastic cell line, a decrease in cell viability was observed from days 1 to 6 for cells exposed to both the sample solution and the controls (Fig. 7). Although ANOVA showed statistical differences among all the samples $\left(P: 6.66 \times 10^{-16}\right)$, the post-hoc analysis did not reveal any difference between the control samples and the zosteric acid sodium salt-treated ones for every time point.

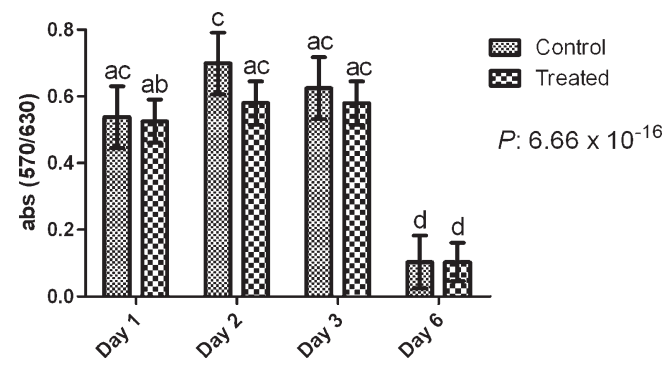

Figure 7 Cellular metabolic activity of murine fibroblast cell L929. The graph provides the $P$ value obtained by ANOVA analysis. Error bars display the honestly significant difference (HSD) intervals using Tukey multiple comparison with a 95\% confidence level (Tukey's HSD, $P<0.05)$. According to post-hoc analysis, means sharing the same letter are not significantly different from each other biofilm before chlorhexidine digluconate treatment. Panels $\mathbf{b}$ and $\mathbf{c}$ show the progressive increase of fluorescence of the control sample at 1 and $2 \mathrm{~h}$ respectively. Panels $\mathbf{e}$ and $\mathbf{f}$ show the progressive increase of fluorescence of the treated samples at 1 and $2 \mathrm{~h}$, respectively

Thus, there was no evidence of cytotoxicity towards murine fibroblast cells.

Zosteric Acid Sodium Salt did not Compromise Cellular Adhesion and Morphology

At the selected time points the cells, taken from human osteosarcoma and L929 cell lines and cultured on standard medium or one supplemented with zosteric acid sodium salt at $10 \mathrm{mg} / \mathrm{L}$ concentration, showed no differences. At 24 and $48 \mathrm{~h}$, the cells were adherent to titanium, and their healthy status is confirmed by the flattened morphology (Fig. 8). Furthermore, on comparing the images taken 24 and $48 \mathrm{~h}$ after seeding for both conditions, more cells can be seen on the titanium at the second time point, suggesting cell proliferation and colonization of the sample surface (Fig. 8).

\section{Discussion}

Since the recognition of zosteric acid as an anti-biofilm compound, most investigations have focused on bacterial biofilms and filamentous fungi. However, little, if anything at all, has been said about the activity of 

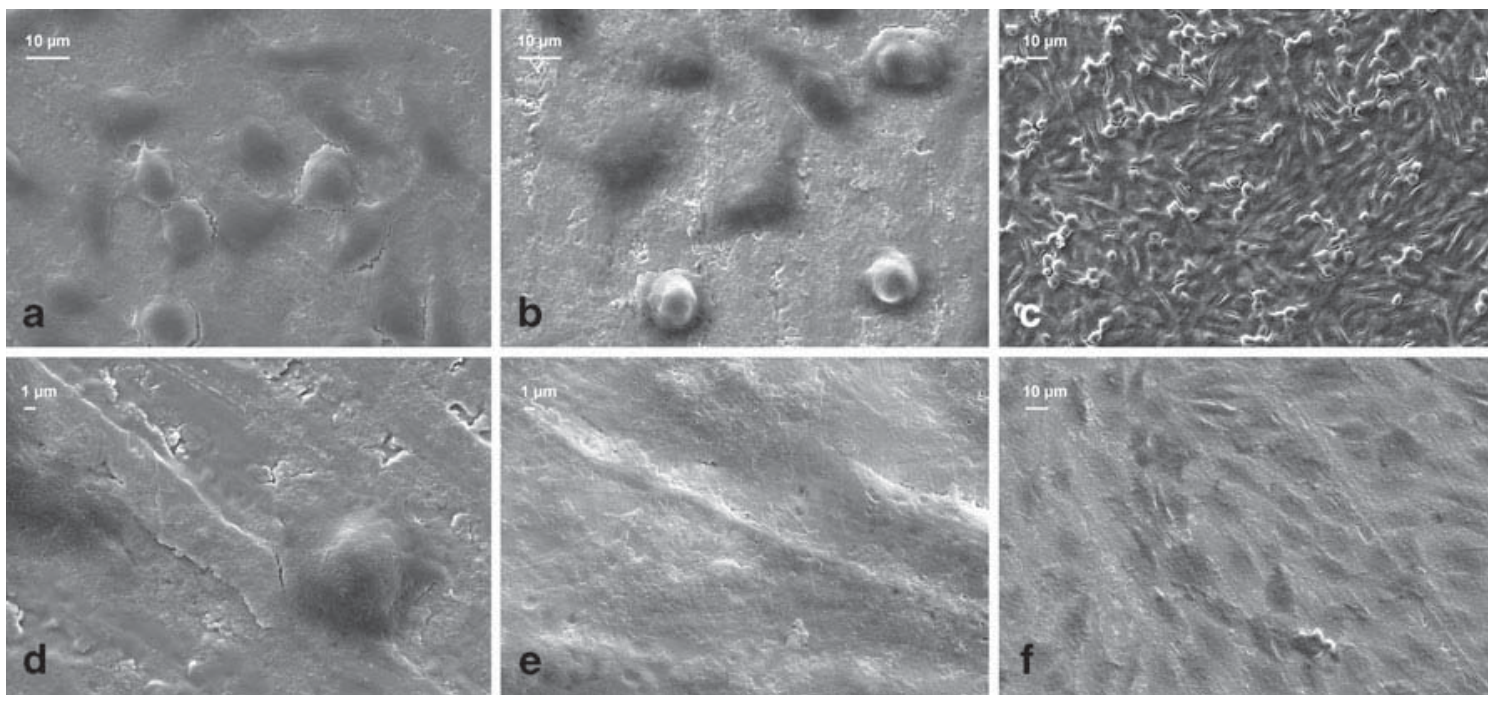

Figure 8 SEM micrographs of murine fibroblast cell line L929 (first line) and human osteosarcoma cell line MG-63 (second line) cultured for $24 \mathrm{~h}(\mathbf{a}-\mathbf{b}, \mathbf{d}-\mathbf{e})$ and $48 \mathrm{~h}(\mathbf{c}, \mathbf{f})$ on titanium surface. Panels a and $\mathbf{d}$

zosteric acid sodium salt against yeast biofilm that has become an escalating industrial and clinical problem. In fact, yeast cells swiftly adapt their adhesion properties to new environments, exploiting their adaptability and capability to form robust biofilm [13, 46]. In an effort to design an experimental model to mimic yeast biofilm, we selected the best-characterized yeast strain $C$. albicans SC5314.

The ability of $C$. albicans to respond to zosteric acid sodium salt in different environmental scenarios was investigated through a model-based experiment design technique (DoE). Using the conventional "One-Variable At a Time" approach, the experimental cost, in terms of time, resource consumption and interpretation of results, is very high since all possible combinations of factor values must be taken into consideration; furthermore, if several factors play a role, their interactions cannot be studied. DoE overcomes these problems as it supports a complex model that predicts how microorganisms interact with their environment, taking into consideration many factors and their interactions, all at the same time [21, 33, 47]. In addition, the DoE models are quite simple just linear terms, two-terms interactions and quadratic terms.

The zosteric acid sodium salt concentration proved to be one of the most important variables, significantly decreasing the number of $C$. albicans adhered cells. On the hydrophilic surface model, there was a contrasting effect on the adhesion process for the variable time. However, the interaction "zosteric acid sodium salt concentration $\times$ time" exerted a significant synergistic effect that impacted the response. Indeed, even though the number of adhered cells increased with time, the presence of the potential antibiofilm agent acted against biofilm formation. show zosteric acid sodium salt-free cells. Panels $\mathbf{b}-\mathbf{c}$ and $\mathbf{e}-\mathbf{f}$ show zosteric acid sodium salt-treated cells

Instead, on the hydrophobic surface, it was interesting to note that the response varied very much as a function of pH. Indeed, Davis et al. [16] reported that C. albicans modifies its morphology according to $\mathrm{pH}$ value, ranging from yeast growth in acidic conditions to hyphae formation in alkaline media. However, as zosteric acid sodium salt is also a potent regulator of yeast-hyphal transition, a critical virulence attribute [1], it thwarts filamentation, and thus successfully counteracted the environmental variable $\mathrm{pH}$ that encourages $C$. albicans biofilm formation.

The regression model showed that zosteric acid sodium salt is active at $10 \mathrm{mg} / \mathrm{L}$, and the maximum response was predicted to be a reduction of cell adhesion by at least $70 \%$ on both hydrophilic and hydrophobic surfaces. The results from the CDC biofilm reactor showed a reduction in biofilm formation, by at least $80 \%$ for both hydrophilic and hydrophobic surfaces, when anti-biofilm compound was added after $C$. albicans inoculation, confirming the results predicted by the mathematical model.

In the absence of the zosteric acid sodium salt, $C$. albicans biofilm formed in a CDC reactor under dynamic conditions with constant medium replacement, presenting a complex heterogeneous 3D structure with both yeast cells and filaments. The resulting biofilm had an abundance of hyphal elements. A similar biofilm structure had previously been observed for a $C$. albicans in vivo system [2, 10, 11]. It is important to note that the presence of the anti-biofilm agent at $10 \mathrm{mg} / \mathrm{L}$ led to a biofilm containing mainly yeast forms and very few filamentous structures, which is advantageous as the absence of filamentous structures greatly reduces biofilm thickness, as was demonstrated by cryosectioning.

The role of morphogenesis in yeast biofilm is less defined. Biofilm produced by wild-type strains of $C$. 
albicans was compared with biofilm formed by two morphological mutants, one incapable of yeast growth, the other of hyphal growth. Dimorphic transition from the yeast form to the filament form plays a pivotal role in the development of the architecture of mature C. albicans biofilm, as strains with defective hypha formation produce only a thin basal layer of densely packed yeast cells, whereas the hypha-negative mutant produced a thicker, but more open, hyphal layer [3, 4, 30, 31, 45]. Although dimorphism is not a prerequisite for biofilm formation, it is necessary for the development of a spatially organized structured biofilm that differs in its ability to colonize a surface and in its virulence [22, 29, 38].

Stokes and colleagues [40] demonstrated that the lower virulence of Candida dubliniensis, compared to C. albicans, was due to its reduced capability to produce hyphae. C. dubliniensis formed a non-invasive layer of yeast along the surface, a layer that was poorly adhered and easily dislodged. In addition, the yeast form is distinct from that of filaments in cell wall structure and composition. Only yeast-form cells possess an exposed $\beta$-glucan at a few sites that can be recognized by pattern recognition receptors of the immune system Dectin-1, which can then mediate subsequent binding and phagocytosis [50]. In contrast, $C$. albicans filaments fail to bind the $\beta$-glucan receptor Dectin-1 and actively penetrate epithelial cells [25, 52].

Zosteric acid sodium salt $(10 \mathrm{mg} / \mathrm{L})$ was also added $24 \mathrm{~h}$ after inoculation, and within $72 \mathrm{~h}$, a hyphae-poor biofilm was observed and the biofilm thickness was much less than that without the anti-biofilm agent. Our findings were similar to those obtained by Stanley and colleagues [39] who observed that the adhered fungal spores were unable to develop infection structures in the presence of zosteric acid.

The anti-biofilm activity of zosteric acid sodium salt has previously been ascribed to the sulfate ester group [39]. We investigated the activity of methyl zosterate, of which the carboxylate moiety is masked by a methyl ester. Interestingly, the methyl zosterate had no anti-biofilm ability, suggesting that the activity of zosteric acid sodium salt is not a specific function of the sulfo-oxy group.

It is widely recognized that the susceptibility of $C$. albicans biofilm to many conventional antimicrobial agents is reduced, compared to the susceptibility of planktonic cells. Therefore, the sensitivity of zosteric acid sodium salttreated biofilm was examined over $72 \mathrm{~h}$ of biofilm formation to determine whether the same recalcitrance occurred. As expected, the heavily perturbed biofilm structure of zosteric acid sodium salt-treated biofilms increased the action of the antimicrobial agents. Even so, the use of chlorine, hydrogen peroxide and cis-2-decenoic acid never achieved complete abatement of $C$. albicans biofilms.

Particularly noteworthy was the observation that cis-2decenoic acid, which mimics the cell-to-cell signaling molecule farnesol (a dispersion promoting agent) [15], improved its potential in the zosteric acid sodium salttreated biofilm. The combination of zosteric acid sodium salt and cis-2-decenoic acid might have important implications for the exogenous induction of the planktonic state [15]. In contrast, the biocide activity of chlorhexidine digluconate greatly increased in the zosteric acid sodium salt-treated system, leading to most of the population being killed within 2 hours.

As judged by the increase in PI fluorescence, the penetration of chlorhexidine digluconate was more rapid in zosteric acid sodium salt-treated biofilm than in untreated biofilm. We speculate that cell membrane integrity suffered more damage from the antimicrobial agent in the treated biofilm rather than did the control. Particularly noteworthy was the observation that, in the zosteric acid sodium saltgrown biofilm, PI penetration into the yeast forms appeared to be greater than for filamentous forms. This result was interesting as it gives further support to the widely recognized strong recalcitrance of budded cells to antimicrobial activity [41]. There was no evidence that any of the treatment caused removal or detachment of biomass from the biofilm. This is an important finding as a dislodged biofilm cluster might act as a vector for new colonization and subsequent infection [44].

With a view to exploring the potential of zosteric acid sodium salt as a surface-based agent in clinical settings, L929 and MG-63 response indicated that $10 \mathrm{mg} / \mathrm{L}$ of zosteric acid sodium salt supports metabolic activity and normal osteoblast and fibroblast adhesion, proliferation and morphology, and zosteric acid sodium salt showed good solubility. This preliminary screening test encourages the use of zosteric acid sodium salt as an innovative prophylactic or integrative approach against yeast biofilms in the medical field. However, further in vitro and in vivo studies will be needed to complete the toxicity investigations.

\section{References}

1. Alem MA, Oteef MD, Flowers TH, Douglas LJ (2006) Production of tyrosol by Candida albicans biofilms and its role in quorum sensing and biofilm development. Eukaryot Cell 5:1770-1779

2. Andes D, Nett J, Oschel P, Albrecht R, Marchillo K, Pitula A (2004) Development and characterization of an in vivo central venous catheter Candida albicans biofilm model. Infect Immun 72:6023-6031

3. Arnaud MB, Costanzo MC, Shah P, Skrzypek MS, Sherlock G (2009) Gene ontology and the annotation of pathogen genomes: the case of Candida albicans. Trends Microbiol 17:295-303

4. Banerjee M, Thompson DS, Lazzell A, Carlisle PL, Pierce C, Monteagudo C, López-Ribot JL, Kadosh (2008) UME6, a novel filament-specific regulator of Candida albicans hyphal extension and virulence. Mol Biol Cell 19:1354-1365

5. Barrios CA, Xu Q, Cutright T, Newby BZ (2005) Incorporating zosteric acid into silicone coatings to achieve its slow release 
while reducing fresh water bacterial attachment. Colloids Surf B Biointerfaces 41:83-93

6. Brugnoni LI, Lozano JE, Cubitto MA (2007) Potential of yeast isolated from apple juice to adhere to stainless steel surfaces in the apple juice processing industry. Food Res Int 40:332-340

7. Callow ME, Callow JA (1998) Attachment of zoospores of the fouling alga Enteromorpha in the presence of zosteric acid. Biofouling 13:87-95

8. Cappitelli F, Principi P, Sorlini C (2006) Biodeterioration of modern materials in contemporary collections: can biotechnology help? Trends Biotechnol 24:350-354

9. Cegelski L, Marshall GR, Eldridge GR, Hultgren SJ (2008) The biology and future prospects of antivirulence therapies. Nat Rev Microbiol 6:17-27

10. Chandra J, Kuhn DM, Mukherjee PK, Hoyer LL, McCormick T, Ghannoum MA (2001) Biofilm formation by the fungal pathogen Candida albicans: development, architecture, and drug resistance. J Bacteriol 183:5385-5394

11. Chandra J, McCormick TS, Imamura Y, Mukherjee PK, Ghannoum MA (2007) Interaction of Candida albicans with adherent human peripheral blood mononuclear cells increases $C$. albicans biofilm formation and results in differential expression of pro- and anti-inflammatory cytokines. Infect Immun 75:2612-2620

12. Chiesa R, Giavaresi G, Fini M, Sandrini E, Giordano C, Bianchi A, Giardino R (2007) In vitro and in vivo performance of a novel surface treatment to enhance osseointegration of endosseous implants. Oral Surg Oral Med O 103:745-756

13. Cottier F, Mühlschlegel FA (2009) Sensing the environment: response of Candida albicans to the $\mathrm{X}$ factor. FEMS Microbiol Lett 295:1-9

14. da Silveira LC, Charone S, Maia LC, Soares RMA, Portela MB (2009) Biofilm formation by Candida species on silicone surfaces and latex pacifier nipples: an in vitro study. J Clin Pediatr Dent 33:235-240

15. Davies DG, Marques CN (2009) A fatty acid messenger is responsible for inducing dispersion in microbial biofilms. J Bacteriol 191:1393-1403

16. Davis D (2003) Adaptation to environmental $\mathrm{pH}$ in Candida albicans and its relation to pathogenesis. Curr Genet 44:1-7

17. Del Curto B, Brunella MF, Giordano C, Pedeferri MP, Valtulina V, Visai L, Cigada A (2005) Decreased bacterial adhesion to surfacetreated titanium. Int J Artif Organs 28:716-730

18. Douglas LJ (2003) Candida biofilms and their role in infection. Trends Microbiol 11:30-36

19. Flemming HC (2005) Alternative and conventional anti-fouling strategies. Int Biodeterior Biodegrad 56:121-134

20. Fonzi WA, Irwin MY (1993) Isogenic strain construction and gene mapping in Candida albicans. Genetics 134:717-728

21. Franceschini G, Macchietto S (2008) Model-based design of experiments for parameter precision: state of the art. Chem Eng Sci $63: 4846-4872$

22. Gantner BN, Simmons RM, Underhill DM (2005) Dectin-1 mediates macrophage recognition of Candida albicans yeast but not filaments. EMBO J 24:1277-1286

23. Giordano C, Sandrini E, Del Curto B, Signorelli E, Di Silvio L (2004) Titanium for osteointegration: comparison between a novel biomimetic treatment and commercially exploited surfaces. J Appl Biomater Biomech 2:35-44

24. Harding MW, Marques LLR, Howard RJ, Olson ME (2009) Can filamentous fungi form biofilms? Trends Microbiol 17:475-480

25. Heinsbroek SEM, Taylor PR, Martinez FO, Martinez-Pomares L, Brown GD, Gordon S (2008) Stage-specific sampling by pattern recognition receptors during Candida albicans phagocytosis. PLoS Pathog 4 (11)

26. Honraet K, Goetghebeur E, Nelis HJ (2005) Comparison of three assays for the quantification of Candida biomass in suspension and CDC reactor grown biofilms. J Microbiol Meth 63:287-295

27. Jagani S, Chelikani R, Kim D-S (2009) Effects of phenol and natural phenolic compounds on biofilm formation by Pseudomonas aeruginosa. Biofouling 25:321-324

28. Jones T, Federspiel NA, Chibana H, Dungan J, Kalman S, Magee BB, Newport G, Thorstenson YR, Agabian N, Magee PT, Davis RW, Scherer S (2004) The diploid genome sequence of Candida albicans. PNAS 101:7329-7334

29. Lewis RE, Lo HJ, Raad II, Kontoyiannis DP (2002) Lack of catheter infection by the efg $1 /$ efg $1 \mathrm{cph} 1 / \mathrm{cph} 1$ double-null mutant, a Candida albicans strain that is defective in filamentous growth. Antimicrob Agents Chemother 46:1244-1248

30. Limjindaporn T, Khalaf RA, Fonzi WA (2003) Nitrogen metabolism and virulence of Candida albicans require the GATA-type transcriptional activator encoded by GAT1. Mol Microbiol 50:993-1004

31. Martchenko M, Alarco AM, Harcus D, Whiteway M (2004) Superoxide dismutases in Candida albicans: transcriptional regulation and functional characterization of the hyphal-induced SOD5 gene. Mol Biol Cell 15:456-467

32. Nailis H, Vandenbroucke R, Tilleman K, Deforce D, Nelis H, Coenye T (2009) Monitoring ALS1 and ALS3 gene expression during in vitro Candida albicans biofilm formation under continuous flow conditions. Mycopathologia 167:9-17

33. Olsson IM, Johansson E, Berntsson M, Eriksson L, Gottfries J, Wold S (2006) Rational DOE protocols for 96-well plates. Chemometr Intell Lab 83:66-74

34. Percec V, Peterca M, Sienkowska MJ, Ilies MA, Aqad E, Smidrkal J, Heiney PA (2006) Synthesis and retrostructural analysis of libraries of $\mathrm{ab} 3$ and constitutional isomeric $\mathrm{ab} 2$ phenylpropyl ether-based supramolecular dendrimers. J Am Chem Soc 128:3324-3334

35. Principi P, Villa F, Sorlini C, Cappitelli F (2010) Molecular studies of microbial community structure on stained pages of Leonardo da Vinci's Atlantic Codex. Microb Ecol. doi:10.1007/ s00248-010-9741-3

36. Qian P-Y, Xu Y, Fusetani N (2010) Natural products as antifouling compounds: recent progress and future perspectives. Biofouling 26:223-234

37. Ramage G, Wickes BL, López-Ribot JL (2007) Inhibition on Candida albicans biofilm formation using divalent cation chelators (EDTA). Mycopathologia 164:301-306

38. Sellam A, Thamir Al-Niemi, McInnerney K, Brumfield S, Nantel A, Suci PA (2009) A Candida albicans early stage biofilm detachment event in rich medium. BMC Microbiol 9:25-25

39. Stanley MS, Callow ME, Perry R, Alberte RS, Smith R, Callow JA (2002) Inhibition of fungal spore adhesion by zosteric acid as the basis for a novel, non-toxic crop protection technology. Phytopatol 92:378-383

40. Stokes C, Moran GP, Spiering MJ, Cole GT, Coleman DC, Sullivan DJ (2007) Lower filamentation rates of Candida dubliniensis contribute to its lower virulence in comparison with Candida albicans. Fungal Genet Biol 44:920-931

41. Suci PA, Tyler BJ (2002) Action of chlorhexidine digluconate against yeast and filamentous forms in an early-stage Candida albicans biofilm. Antimicrob Agents Chemother 46:3522-3531

42. Thewes S, Moran GP, Magee BB, Schaller M, Sullivan DJ, Hube B (2008) Phenotypic screening, transcriptional profiling, and comparative genomic analysis of an invasive and non-invasive strain of Candida albicans. BMC Microbiol 8:187

43. Todd JS, Zimmerman RC, Crews P, Alberte RS (1993) The antifouling activity of natural and synthetic phenol acid sulphate esters. Phytochemistry 34:401-404

44. Uppuluri P, Chaturvedi AK, Srinivasan A, Banerjee M, Ramasubramaniam AK, Köhler JR, Kadosh D, Lopez-Ribot JL 
(2010) Dispersion as an important step in the Candida albicans biofilm developmental cycle. PLoS Pathog 6:e1000828

45. Van Dijck P, De Rop L, Szlufcik K, Van Ael E, Thevelein JM (2002) Disruption of the Candida albicans TPS2 gene encoding trehalose-6-phosphate phosphatase decreases infectivity without affecting hypha formation. Infect Immun 70:1772-1782

46. Verstrepen KJ, Klis FM (2006) Flocculation, adhesion and biofilm formation in yeasts. Mol Microbiol 60:5-15

47. Villa F, Albanese D, Giussani B, Stewart PS, Daffonchio D, Cappitelli F (2010) Hindering biofilm formation with zosteric acid. Biofouling 26:739-752

48. Vogel C, Rogerson A, Schatz S, Laubach H, Tallman A, Fell J (2007) Prevalence of yeasts in beach sand at three bathing beaches in South Florida. Water Res 41:1915-1920
49. Watamoto T, Samaranayake LP, Jayatilake JAMS, Egusa H, Yatani H, Seneviratne CJ (2009) Effect of filamentation and mode of growth on antifungal susceptibility of Candida albicans. Int $\mathbf{J}$ Antimicrob Agents 34:333-339

50. Wheeler RT, Kombe D, Agarwala SD, Fink GR (2008) Dynamic, morphotype-specific Candida albicans $\beta$-glucan exposure during infection and drug treatment. PLoS Pathog $4(12)$.

51. Xu Q, Barrios CA, Cutright T, Newby BZ (2005) Assessment of antifouling effectiveness of two natural product antifoulants by attachment study with freshwater bacteria. Environ Sci Pollut Res $12: 278-284$

52. Zhu W, Filler SG (2010) Interactions of Candida albicans with epithelial cells. Cell Microbiol 12:273-282 